\title{
HAEMATOLOGICAL AND BIOCHEMICAL VALUES IN THE PERIPHERAL BLOOD OF CAPE HUNTING DOGS KEPT IN THE EAST-BOHEMIAN ZOOLOGICAL GARDEN AT DVUR KRÃLOVE NAD LABEM
}

\author{
J. POSPISIL, J. VÁHALA, P. ŚPÁLA and F. KAŠSE
}

East-Bohemian Zoological Garden, 55401 Dvůr Králové nad Labem

Received August 26, 1986

\begin{abstract}
P o s p i šil 1 J., J. V á h a 1 a, P. S p á 1 a, F. $\mathrm{K}$ a s e: Haematological and Biochemical Values in the Peripheral Blood of Cape Hunting Dogs Kept in the East-Bohemian Zoological Garden at Duir Krälové nad Labem. Acta vet. Brno, 56,1987:195-205.

Thirteen clinically healthy cape hunting dogs (Lycaon pictus) kept in the East-Bohemian Zoological Garden at Dvůr Králové nad Labem were subjected to haematological and biochemical examination of the peripheral blood. The report gives the results of their haematological examination covering erythrocyte count, haemoglobin content, haematocrit, mean corpuscular haemoglobin, mean corpuscular haemoglobin concentration, mean corpuscular volume, leukocyte count and differential leukocyte count and those of biochemical examination of their blood sera covering total protein, glucose, creatinine, urea, triglyceride, cholesterol, magnesium, calcium, phosphorus, chloride, sodium, potassium, copper, zinc and iron level and alkaline phosphatase and AST and ALT aminotransferase activity, all expressed as mean values. The values were compared with those reported in the literature for the peripheral blood of the dog (Canis familiaris).

Lycaon pictus, haematology, blood serum, biochemistry.
\end{abstract}

Systematic examination of haematological and biochemical values in the peripheral blood of clinically healthy animals kept in the East-Bohemian Zoological Garden at Dvůr Králové nad Labem has been carried out for several years ( $\mathrm{P} \circ \mathrm{s} \mathrm{p}$ i š $\mathrm{i} l$ et al. $1984 \mathrm{abcd}$; 1985ab). The present study is concerned with haematological and biochemical values in the peripheral blood of cape hunting dogs (Lycaon pictus) reared successfuly in this zoo for a number of years. To our knowledge, no published data are available on biochemical values in the peripheral blood of this animal species and only $\mathrm{H}$ a w $\mathrm{k}$ e y (1975) reported haemotological values obtained in two cape hunting dogs. 


\section{Materials and Methods}

Cape hunting dogs (Lycaon pictus) kept in the East-Bohemian Zoological Garden at Dvúr Králové nad Labem were housed in a house designed for this animal species. Heating was provided in winter and the animals had access to an open-air enclosure throughout the year. In summer they spent most of the time in the open-air enclosure. They were fed beef or veal three times a week, a mixture consisting of minced meat, oat flakes, carrot, milk-powder, yeast, minerals- and vitamins-containing concentrate and vegetable oil twice a week, living feed (rabbit, coypu, hen) once a week and were offered no feed once a week.

The animals were in good health, the only problem being occasional injury to the skin or limbs.

Before blood collection the animals were immobilized by i.m. administration of ketamin (NARCAMON SPOFA) $(80-160 \mathrm{mg}$ per animal) given concurrently with xylazine (ROMPUN BAYER) $(70$ - $140 \mathrm{mg}$ per animal) and then blood-sampled from the vena saphena. A total of 7 male and 6 female cape hunting dogs were examined. Their age and the season of examination are shown in Table 1 .

Table 1. Age of cape hunting dogs (Lycaon pictus) examined and the season of examination

\begin{tabular}{|l||c|l|l|}
\hline Sex & $\begin{array}{l}\text { No. } \\
\text { animals }\end{array}$ & $\begin{array}{l}\text { Month when animal } \\
\text { examined / No. blood } \\
\text { collections }\end{array}$ & Age in years / No. animals \\
\hline males & 7 & II/3, VI/2, VII/1, IX/1 & $1 / 2,2 / 2,3 / 1,4 / 1,5 / 1$ \\
\hline females & 6 & II/6 & $2 / 4,5 / 2$ \\
\hline
\end{tabular}

All haematological values were determined by standard techniques as used in clinical practice ( $\mathrm{J}$ a $\mathrm{n}$ e $1 \mathrm{e}$ et al. 1981). Their detailed description was presented in our previous reports ( $\mathrm{P} \circ \mathrm{s} \mathrm{p}$ í š i l et al. 1984a, 1985a).

For exploratory assessment of the effects of the immobilizing procedure on haemotological values in the peripheral blood, three cape hunting dogs were examined at three intervals after injection of the immobilizing agents.

Biochemical values were determined in the blood serum. The methods used can be divided into two groups. One group comprised techniques using kits supplied by LACHEMA, Brno, and carried out according to the producer's instructions. In this way total protein and glucose, creatine, urea, triglyceride, cholesterol, chloride and phosphorus level and alkaline phosphatase and ALT and AST aminotransferase activity were determined. Spectrophotometric measurements were made with a PM2K OPTION spectrophotometer. The other group of the methods comprised techniques based on atomic absorption spectrophotometry. This approach was chosen for the determination of calcium, magnesium, potassium, sodium, iron, copper and zinc level. The spectrophotometer used was a PERKIN-ELMER 2380 and the determinations were made according to the producer's instructions. The validity of the results obtained with the two methods was checked by including samples of control sera (CALIBRATE, LABORDIAGNOSTICA, Gödecke, GFR).

Means (X) and standard deviations (S.D.) were computed separately for male and female animals. The significance of the difference of the means between males and females was analysed using Student's t-test. 


\section{Results}

The results of haematological examination of the peripheral blood are presented in Table 2 and those of biochemical examination of the blood serum are presented in Tables 3 and 4 . The difference of the means of the haematological and biochemical values between males and females were not significant except for erythrocyte count and sodium level where at the 3.18 and 4.48 levels of significance, respectively. The difference between males and females in all the other values were not significant (at the 58 level).

The results of exploratory examination of the effects of the immobilizing procedure on haematological values of the peripheral blood in three cape hunting dogs are presented in Table 5. It can be seen that the immobilizing agents exerted no marked effects on haematological values of the peripheral blood at the post-administration intervals under study.

\section{Dis cussion}

For comparison with the haematological values in te peripheral blood of cape hunting dogs obtained in the present study only the data presented by $\mathrm{H}$ a w $\mathrm{k}$ e y (1975) were available. Our findings (Table 2) differed from those presented by the aforementioned writer particularly in erythrocyte count and haemoglobin content. In these two instances the values obtained by us were higher, whereas our haematocrit value was lower than that reported by $\mathrm{H}$ a $\mathrm{w}$ k y (1975). These differences in basic erythrocyte values are then responsible for considerable differences in the values computed from them (mean corpuscular haemoglobin, mean corpuscular haemoglobin concentration and mean corpuscular volume). Moreover, the leukocyte count (based on examination of one cape hunting dog) in Hawkey's monograph (1975) is lower than our result, although only little difference was found in the differential leukocyte count. The reasons for the differences in individual haematological values of the peripheral blood of the cape hunting dog are difficult to assess. In both cases the number of cape hunting dogs examined were small ( 2 in $H$ a $w$ k e y 's (1975) study and 13 in our report), the animals used in the two studies were kept under different husbandry conditions and the results of examination were influenced by !'oth biological and analytical factors. Furthermore, the peripheral blood values under study may also have been affected, to a certain extent, by age of the animals as was reported for the dog (Canis familiaris) by $S$ c h a $1 \mathrm{~m}$ (1975) and $\mathrm{K}$ i r $\mathbf{k}$ (1980). However, the number of cape hunting dogs of differing age within the range of 1 - to 5-year old animals in our study was too small to permit classification into age groups where such assessment could have been made.

Comparison of the haematological values found by us in the peripheral blood of cape hunting dogs with those reported for the dog (Canis familiaris) is possible, although not fully justified considering that such comparison is made between two different species of the dog family, the latter of which is kept under quite different conditions and is blood-sampled without previous administration of any immobilizing agents. In spite of these and some other differences haematological findings in the dog will probably continue to be used for comparison in such cases because of their availability. The question was which out of a number of haematological findirigs in the dog by various investigations as reported by $\mathrm{S} c \mathrm{~h}$ a $1 \mathrm{~m}$ (1975) and summarized in a 


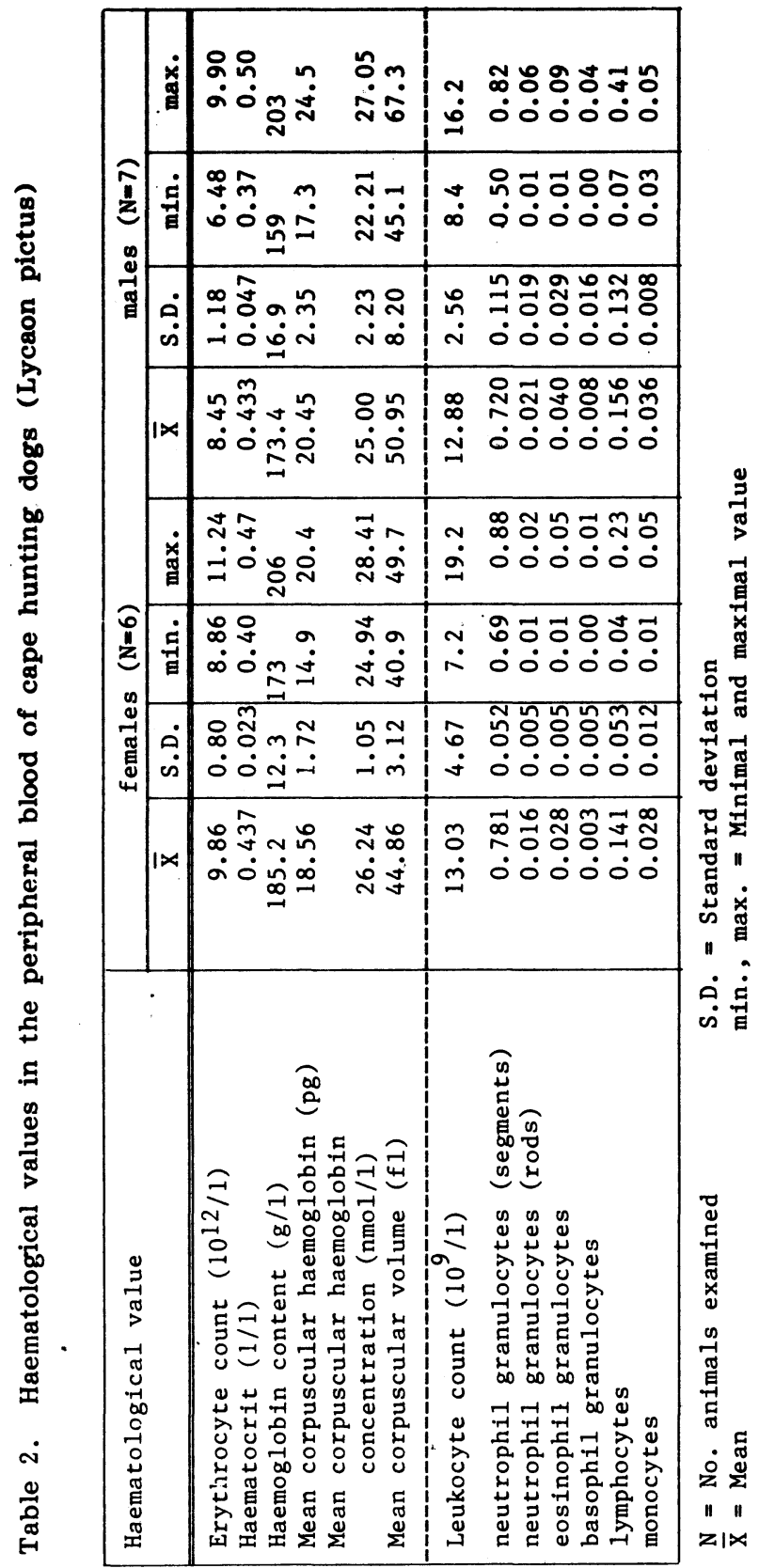


Table 3. Changes of haematological values in the peripheral blood of cape hunting dogs (Lycaon pictus) after i.m. administration of KETAMIN and XYLAZINE

$(\mathrm{N}=3)$

\begin{tabular}{|c|c|c|c|}
\hline \multirow{2}{*}{ Haematological value } & \multicolumn{3}{|c|}{ time of administration } \\
\hline & $8-12$ min. & $20-21$ min. & $30-31 \mathrm{~min}$. \\
\hline Erythrocyte count $\left(10^{12 / 1)}\right.$ & $\begin{array}{r}9.08 \\
\pm 0.39\end{array}$ & $\begin{array}{r}8.99 \\
\pm 0.13\end{array}$ & $\begin{array}{r}8.80 \\
\pm 0.14\end{array}$ \\
\hline Haemoglobin content $(g / 1)$ & $\begin{array}{r}172.6 \\
\pm 4.16\end{array}$ & $\begin{array}{r}175.3 \\
\pm 6.8\end{array}$ & $\begin{array}{r}171.3 \\
\pm 5.5\end{array}$ \\
\hline Haematocrit $(1 / 1)$ & $\begin{array}{r}0.413 \\
\pm 0.011\end{array}$ & $\begin{array}{r}0.410 \\
\pm 0.026\end{array}$ & $\begin{array}{r}0.406 \\
\pm 0.030\end{array}$ \\
\hline $\begin{array}{l}\text { Mean corpuscular haemo- } \\
\text { globin (pg) }\end{array}$ & $\begin{array}{l}18.74 \\
\pm 1.15\end{array}$ & $\begin{array}{l}19.46 \\
\pm 0.76\end{array}$ & $\begin{array}{l}18.50 \\
\pm 0.96\end{array}$ \\
\hline $\begin{array}{l}\text { Mean corpuscular haemo- } \\
\text { globin concentration (nmol/1) }\end{array}$ & $\begin{array}{l}25.87 \\
\pm 1.05\end{array}$ & $\begin{array}{l}26.92 \\
\pm 0.49\end{array}$ & $\begin{array}{l}26.18 \\
\pm 1.48\end{array}$ \\
\hline Mean corpuscular volume ( $f 1$ ) & $\begin{array}{l}44.9 \\
\pm 2.5\end{array}$ & $\begin{array}{l}44.8 \\
\pm 1.9\end{array}$ & $\begin{array}{l}46.2 \\
\pm 4.2\end{array}$ \\
\hline Leukocyte count $\left(10^{9} / 1\right)$ & $\begin{array}{l}11.7 \\
\pm 1.5\end{array}$ & $\begin{array}{l}11.7 \\
\pm 2.29\end{array}$ & $\begin{array}{l}14.2 \\
\pm 1.04\end{array}$ \\
\hline $\begin{array}{c}\text { neutroph11 granulocytes } \\
\text { (segments) }\end{array}$ & $\begin{array}{r}0.766 \\
\pm 0.020\end{array}$ & $\begin{array}{r}0.725 \\
\pm 0.077\end{array}$ & $\begin{array}{r}0.766 \\
\pm 0.032\end{array}$ \\
\hline $\begin{array}{c}\text { neutrophil granulocytes } \\
\text { (rods) }\end{array}$ & $\begin{array}{l}0.010 \\
\pm 0.00\end{array}$ & $\begin{array}{l}0.020 \\
\pm 0.00\end{array}$ & $\begin{array}{r}0.016 \\
\pm 0.005\end{array}$ \\
\hline eosinophil granulocytes & $\begin{array}{r}0.026 \\
\pm 0.015\end{array}$ & $\begin{array}{r}0.033 \\
\pm 0.005\end{array}$ & $\begin{array}{r}0.036 \\
\pm 0.011\end{array}$ \\
\hline basophil granulocytes & \pm 0.000 & \pm 0.000 & \pm 0.000 \\
\hline 1ymphocytes & $\begin{array}{r}0.170 \\
\pm 0.000\end{array}$ & $\begin{array}{r}0.163 \\
\pm 0.066\end{array}$ & $\begin{array}{r}0.116 \\
\pm 0.011\end{array}$ \\
\hline monocytes & $\begin{array}{r}0.026 \\
\pm 0.011\end{array}$ & $\begin{array}{r}0.036 \\
\pm 0.005\end{array}$ & $\begin{array}{r}0.036 \\
\pm 0.011\end{array}$ \\
\hline
\end{tabular}

previous study by one of us ( $\mathrm{P} \circ \mathrm{s} \mathrm{p}$ íš $\mathrm{i} l$ and $\mathrm{K} \circ \mathrm{m}$ á $\mathrm{r}$ e $\mathrm{k}$ 1963) were to be chosen for this comparison. In the light of our previous studies ( $\mathrm{P}$ o s p i s i l et al. $1984 \mathrm{abcd} ; 1985 \mathrm{ab}$ ) we chose those of $\mathrm{S}$ c $\mathrm{h} \mathrm{a} 1 \mathrm{~m}$ (1975) and $\mathrm{S}$ o $\mathrm{v}$ a (1979) regarding such values as markedly different that did not overlap in terms of standard deviations or range. The results of this comparison are shown in Table 7. 
Table 4. Biochemical values in the blood serum of cape hunting dogs (Lycaon pictus) (males)

\begin{tabular}{|c|c|c|c|c|c|c|}
\hline \multicolumn{2}{|c|}{ Biochemical value, } & \multirow{2}{*}{$\frac{N}{6}$} & \multirow{2}{*}{$\frac{\bar{x}}{65.16}$} & \multirow{2}{*}{$\frac{S . D .}{11.08}$} & \multicolumn{2}{|c|}{$\min .-\max$} \\
\hline Protein & $8 / 1$ & & & & 54.0 & -80.0 \\
\hline Glucose & $\mathrm{mmol} / 1$ & 6 & 9.20 & 1.16 & 8.4 & -10.9 \\
\hline Creatinine & $\mu \mathrm{mol} / 1$ & 6 & 115.0 & 22.9 & 74.0 & -135.0 \\
\hline Urea & $\mathrm{mmol} / 1$ & 7 & 11.92 & 4.2 & 3.7 & -16.6 \\
\hline Triglycerides & $\mathrm{mmo1} / 1$ & 6 & 2.52 & 0.53 & 1.64 & 2.99 \\
\hline Cholesterol & $\operatorname{mmol} / 1$ & 7 & 5.12 & 0.96 & 4.0 & -6.9 \\
\hline $\begin{array}{l}\text { Alkaline } \\
\text { phosphatase }\end{array}$ & $\mu \mathrm{kat} / 1$ & 5 & 0.476 & 0.522 & 0.16 & 1.40 \\
\hline AST & $\mu \mathrm{kat} / 1$ & 7 & 0.368 & 0.132 & 0.20 & 0.54 \\
\hline ALT & $\mu \mathrm{kat} / 1$ & 7 & 0.412 & 0.214 & 0.15 & 0.72 \\
\hline Magnesium & $\operatorname{mmol} / 1$ & 7 & 0.931 & 0.088 & 0.74 & 1.01 \\
\hline Calcium & $\operatorname{mmol} / 1$ & 7 & 2.141 & 0.207 & 1.78 & 2.32 \\
\hline Phosphorus & $\operatorname{mmol} / 1$ & 7 & 1.262 & 0.531 & 1.09 & 1.75 \\
\hline Chlorides & $\mathrm{mmol} / 1$ & 7 & 113.3 & 7.9 & 97.0 & -119.0 \\
\hline Sodium & $\mathrm{mmol} / 1$ & 7 & 148.1 & 6.9 & 139.0 & -157.0 \\
\hline Potassium & $\mathrm{mmol} / 1$ & 7 & 4.560 & 0.496 & 3.95 & 5.19 \\
\hline Copper & $\mu \mathrm{mol} / 1$ & 5 & 10.12 & 9.93 & 2.4 & -21.4 \\
\hline Zinc & $\mu \mathrm{mol} / 1$ & 5 & 25.58 & 12.08 & 13.8 & -45.4 \\
\hline Iron & $\mu \mathrm{mol} / 1$ & 4 & 14.02 & 9.90 & 7.9 & -28.8 \\
\hline
\end{tabular}

For explanation of the symbols see Table 2 .

As to biochemical values in the blood serum of cape hunting dogs, no published data were available to us for comparison. Therefore we compared our findings only with those obtained for the dog (Canis familiaris), using the data reported by $\mathrm{S} \circ \mathrm{v}$ a (1979), J a $\mathrm{g} \circ \mathrm{s}$ and $\mathrm{B} \circ \mathrm{u} \mathrm{d}$ a (1981 and $\mathrm{K}$ i r $\mathrm{k}$ (1980) and adhering to the same criteria as were used by us in comparing the haematological values. The biochemical values in the blood serum of the dog quoted by K i r k (1980) are those used by N.Y.S. Veterinary College, Cornell University. The results of the comparison are shown in Table 8.

As can be seen from Table 7 and 8 the largest differences between the peripheral blood values of cape hunting dogs and those reported for the dog (Canis familiaris) were found in erythrocyte count and glucose level. To 
Table 5. Biochemical values in the blood serum of cape hunting dogs (Lycaon pictus) (females)

\begin{tabular}{|c|c|c|c|c|c|c|}
\hline \multicolumn{2}{|c|}{ Biochemical value } & \multirow{2}{*}{$\frac{N}{6}$} & \multirow{2}{*}{$\frac{\bar{x}}{73.83}$} & \multirow{2}{*}{$\frac{\text { S.D. }}{7.57}$} & \multicolumn{2}{|c|}{$\min$. - max. } \\
\hline Protein & $8 / 1$ & & & & 65.0 & -84.0 \\
\hline Glucose & $\operatorname{mmol} / 1$ & 6 & 8.53 & 2.18 & 6.3 & -12.5 \\
\hline Creatinine & $\mu \mathrm{mol} / 1$ & 6 & .141 .1 & 28.3 & 112.0 & -182.0 \\
\hline Urea & mmol/1 & 6 & 10.13 & 5.46 & 4.8 & -17.3 \\
\hline Triglycerides & $\mathrm{mmol} / 1$ & 6 & 2.63 & 0.60 & 1.84 & 3.37 \\
\hline Cholesterol & $\mathrm{mmol} / 1$ & 6 & 5.26 & 0.67 & 4.6 & 6.1 \\
\hline $\begin{array}{l}\text { Alkaline } \\
\text { phosphatase }\end{array}$ & S $\mu k a t / 1$ & $\cdot 6$ & 0.456 & 0.415 & 0.13 & 1.24 \\
\hline AST & S $\mu k a t / 1$ & 6 & 0.500 & 0.078 & 0.43 & 0.65 \\
\hline ALT & S kat $/ 1$ & 6 & 0.271 & 0.075 & 0.18 & 0.38 \\
\hline Magnesium & mmol/1 & 6 & 0.915 & 0.056 & 0.86 & 0.99 \\
\hline Calcium & $\mathrm{mmol} / 1$ & 6 & 2.155 & 0.116 & 1.95 & 2.30 \\
\hline Phosphorus & $\operatorname{mmol} / 1$ & 6 & 1.125 & 0.361 & 0.92 & 1.56 \\
\hline Chlorides & $\operatorname{mmol} / 1$ & 6 & 115.5 & 2.8 & 112.0 & -119.0 \\
\hline Sodium & $\mathrm{mmol} / 1$ & 6 & 148.5 & 12.4 & 126.0 & -160.0 \\
\hline Potassium & $\mathrm{mmol} / 1$ & 6 & 4.06 & 0.223 & 3.77 & 4.36 \\
\hline Copper & $\mu \mathrm{mol} / 1$ & 4 & 5.12 & 3.57 & 2.0 & 9.3 \\
\hline Zinc & $\mu \mathrm{mol} / 1$ & 4 & 20.85 & 4.09 & 15.3 & $-\quad 26.2$ \\
\hline Iron & $\mu \mathrm{mol} / 1$ & 4 & 9.40 & 4.48 & 4.7 & -13.9 \\
\hline
\end{tabular}

For explanation of the symbols see Table 2 .

which extent the higher blood serum glucose level found in cape hunting dogs is a consequence of intervention into the neuroendocrine control at blood collection or is species-specific is difficult to decide. In our view a response to non-specific load ( $\mathrm{c}$ h $r$ e i b e r 1985) produced by handling and treatment of the animals before blood collection is more probable. As to the higher erythrocyte count, however, the foregoing explanations is, to a certain extent, at variance with our exploratory studies on haematological changes in three cape hunting dogs at various intervals after administration of KETAMIN and XYLAZINE.

The objective of our systematic studies of haematological and biochemical values in the peripheral blood of clinically healthy animals kept in the East-Bohemian Zoological Garden at Dvůr Králové nad Labem is to provide information that would be of help in diagnosing disease on the basis of 
Table 6. Haematological values in the peripheral blood of cape hunting dogs (Lycaon pictus) as reported by Hawkey (1975)

\begin{tabular}{|c|c|c|c|c|}
\hline Haenatological value & $\mathbf{N}$ & $\overline{\mathbf{x}}$ & Range & \\
\hline Erythrocyte count $\left(10^{12 / 1}\right)$ & 2 & 7.17 & 6.74 & -7.60 \\
\hline Haematocrit (1/1) & 2 & 0.485 & 0.480 & -0.490 \\
\hline Haenoglobin $(g / 1)$ & 2 & 158 & 149 & -168 \\
\hline Mean corpuscular haemoglobin (pg) & 2 & 22.2 & 19.5 & -24.9 \\
\hline $\begin{array}{l}\text { Mean corpuscular haemoglobin } \\
\text { concentration }(\operatorname{mon} 1 / 1)\end{array}$ & 2 & 20.94 & 19.18 & -22.76 \\
\hline Mean corpuscular volume (f1) & 2 & 68.2 & 65.0 & -71.5 \\
\hline Leukocytes $\left(10^{9 / 1}\right)$ & 1 & 4.1 & & \\
\hline neutrophil granulocytes & 1 & 0.760 & & \\
\hline eosinophil granulocytes & 1 & 0.035 & & \\
\hline basoph1l granulocytes & 1 & 0.000 & & \\
\hline lymphocytes & 1 & 0.150 & & \\
\hline monocytes & 1 & 0.055 & & \\
\hline
\end{tabular}

For explanation of the symbols see Table 2 .

The values reported by Hawkey (1975) are expressed here in terms of S.I. units for the sake of comparison.

clinical and laboratory examination. Moreover, our studies along this line in a number of animal species are a contribution to comparative animal physiobogy in general.

Hematologické a biochemické hodnoty periferní krve psů hyenových (Lycaon pictus) chovaných ve Východoceské zoologické zahradè Dvír Králové nad Labem

V práci je referováno o výsledcích hematologického a biochemického vyŠetrení periferní krve 13 klinicky zdravých psủ hyenových (Lycaon Pictus) chovaných ve Východočeské zoologické zahradĕ Dvủr Králové nad Labem. Byly stanoveny prúměrné hơdnoty počtu Červených krvinek, obsahu hemoglobinu, hematokritu, středního množství hemoglobinu červené krvinky, střední koncentrace hemoglobinu Cervené krvinky, středního objemu cervené krvinky, požtu bílých krvinek, zastoupení jednotlivých druhú bílých krvinek. V krevnim séru byly stanoveny prưmérné hodnoty hladiny bilkovin, glukózy, kreatininu, mox̌oviny, trig!yceridủ, cholesterolu, hoł̌́íku, vápníku, fosforu, chloridú, sodíku, draslíku, mědi, zinku, železa a aktivity alkalické forfatázy, aminotransferázy AST a ALT. Dosažené hodnoty byly porovnány $s$ hodnotami udávanými $v$ periferní krvi psa (Canis familiaris). 
Table. 7. Comparison of haematological values in the peripheral blood of cape hunting dogs (Lycaon pictus) with those reported for the dog (Canis famillaris)

\begin{tabular}{|l|c|c|}
\hline \multicolumn{1}{|c|}{ Value compared } & $\begin{array}{c}\text { SCHALM } \\
\text { et al. } \\
1975\end{array}$ & $\begin{array}{c}\text { SOVA } \\
197\end{array}$ \\
\hline Erythrocyte count & $\Delta$ & $\Delta$ \\
\hline Haematocrit & 0 & $\nabla$ \\
\hline Haemoglobin content & 0 & 0 \\
\hline Mean corpuscular haemoglobin & $\nabla$ & $\nabla$ \\
\hline Mean corpuscular haemoglobin concentration & $\Delta$ & $t$ \\
\hline Mean corpuscular volume & $\nabla$ & $\nabla$ \\
\hline Leukocyte count & 0 & 0 \\
\hline neutrophil granulocytes (segments) & 0 & $\Delta$ \\
\hline neutrophil granulocytes (rods) & 0 & Not mentioned \\
\hline eosinophil granulocytes & 0 & $\circ$ \\
\hline basophil granulocytes & $\circ$ & 0 \\
\hline lymphocytes & 0 & $\circ$ \\
\hline monocytes & & 0 \\
\hline
\end{tabular}

$\Delta=$ Peripheral blood value found in cape hunting dogs is higher that that - reported for the dog.

0 - Peripheral blood value found in cape hunting dogs shows little difference from that reported for the dog.

$\nabla=$ Peripheral blood value found in cape hunting dogs is lower than that reported for the dog.

Гематологические и биоцхимические величины периферической крови гиенообразных собах (Lycaon pictus), содержащихся в Восточночешском зоопарке Двур-кралове над Лабой

В работе приводятся результаты гематологического и биохимического исследований периферической крови 13 клинически здоровых coбax (Lycaon pictus, содержимых в Восточночешском зоопарке Двур-Кралове над Лабой. Определяли средние величины красных кровяных телей, содержания гемоглобина, гематокрита, среднего количества гемоглобина, красные тельца, средней концентрации гемоглобина красные тельца, среднего объема красных телец, числа белых телец, представительства отдельных видов белых кробяных телец. В кровяной Сыворотке определяли средние величины уровня белков, глюкозы, креатинина, мочевины, триглицеринов, холестери- 
Table 8. Comparison of biochemical values in the blood serum of cape hunting dogs (Lycaon pictus) with those reported for the dog (Canis familiaris)

$a=$ males

b = females

\begin{tabular}{|c|c|c|c|c|c|c|}
\hline \multirow[t]{2}{*}{ Value compared } & \multicolumn{2}{|c|}{$\begin{array}{l}\text { SOVA } \\
1975\end{array}$} & \multicolumn{2}{|c|}{$\begin{array}{l}\text { JAGOS } \\
\text { BOUDA } \\
1981\end{array}$} & \multicolumn{2}{|c|}{$\begin{array}{l}\text { KIRK } \\
1980\end{array}$} \\
\hline & a & b & & b & $\mathbf{a}$ & $\mathbf{b}$ \\
\hline Protein & $\circ$ & $\circ$ & ○ & $\circ$ & $\circ$ & 0 \\
\hline Glucose & $\Delta$ & $\Delta$ & $\Delta$ & $\Delta$ & $\Delta$ & $\Delta$ \\
\hline Creatinine & $\circ$ & $\circ$ & $\circ$ & 0 & $\circ$ & 0 \\
\hline Urea & $\circ$ & $\circ$ & $\Delta$ & $\Delta$ & $\Delta$ & $\Delta$ \\
\hline Triglycerides & \multicolumn{2}{|c|}{ Not mentioned } & $\Delta$ & $\Delta$ & +10 & 0 \\
\hline Cholesterol & $\circ$ & $\circ$ & ० & o & ○ & $\circ$ \\
\hline Alkaline phosphatase & \multicolumn{2}{|c|}{ Not mentioned } & $\circ$ & $\circ$ & $\circ$ & $\circ$ \\
\hline AST & \multicolumn{2}{|c|}{ Not mentioned } & $\circ$ & $\Delta$ & $\circ$ & $\circ$ \\
\hline ALT & \multicolumn{2}{|c|}{ Not mentioned } & $\circ$ & $\circ$ & $\circ$ & $\circ$ \\
\hline Magnesium & $\Delta$ & $\Delta$ & $\circ$ & o & o & 0 \\
\hline Calcium & o & $\circ$ & $\circ$ & 0 & o & $\circ$ \\
\hline Phosphorus & $\circ$ & $\circ$ & ○ & $\circ$ & $\circ$ & 0 \\
\hline Chlorides & o & $\Delta$ & $\circ$ & $\circ$ & $\circ$ & $\circ$ \\
\hline Sodium & $\Delta$ & $\circ$ & o & o & $\circ$ & 0 \\
\hline Potassium & $\circ$ & $\nabla$ & o & $\nabla$ & o & 0 \\
\hline Copper & $\begin{array}{l}\text { Not } \\
\text { tior }\end{array}$ & & $\begin{array}{l}\text { No } \\
\text { tic }\end{array}$ & en- & & $\begin{array}{l}\text { men- } \\
\text { ed }\end{array}$ \\
\hline Zinc & $\begin{array}{l}\text { Not } \\
\text { tior }\end{array}$ & & $\begin{array}{l}\text { Not } \\
\text { tic }\end{array}$ & $\mathrm{e}^{n-}$ & & men- \\
\hline Iron & $\nabla$ & $\nabla$ & o & $\nabla$ & ० & $\nabla$ \\
\hline
\end{tabular}

Symbols are the same as used in Table 7.

+ Kirk (1980) using data of N.Y.S. Veterinary College, Cornell University, did not mention the value, but this was presented in the relevant chapter by Bentinck-Smith (1980). 
ва, магния, халия, фосфора, хлоридов, ватрия, хальция, меди, цинха, железа и активность шелочной фосфатазы, амивотрансферазы AST и ALT. Получевные величины сопоставляли с величинамихрови cobaxn (Canis familiaris).

\section{References}

BENTNICK-SMITH, J.: A Roster of Normal Values for Dogs and Cats. str. 13211330 In: KIRK, R.W.: Corrent Veterinary Therapy VII. Small Animal

Practice. W., B., Saunders Comp. Philadelphia, London, Toronto, 1980, $1360 \mathrm{p}$.

HAWKEY, C.M.: Comparative Mammallan Haematology-Cellular Components and Blood Coagulation of Captive Wild Animals. William Heinemann Medical Books LTD., London, 1975, 310 p.

JAGOS, P. - BOUDA, J.: Základní biochemické a haematologické hodnoty u domácích zvířat a nové zpủsoby vyjadřování výsledkủ laboratorních vyšet f̌ení. Klub přátel Vysoké školy veterinární, Brno, 1981, 29 p.

JANELE, J. - CIESLAR, P. - HRODEK, 0. - MALASKOVA, V. - POCH, T. - VORLOVA, Z.: Haematologické vyšetřovací metody. Ceská haematologická společnost, Praha, $1980,32 \mathrm{p}$.

KIRR, R.W.: Current Veterinary Therapy VII. Small Animal Practice. W.B. Saunders Comp., Philadelphia, London, Tóronto, 1980, 1360 p.

POSPIŠIL, J. - KAŠE, F. - VAHALA, J. - MOUCHOVA, I.: Basic haematological values in Antelopes I. Comp. Biochem. Physiol., 78 A, 1984a: 347-351.

POSPIŠIL, J. - RASE, F. - VAHALA, J. - MOUCHOVA, I.: Basic haematological values in Antelopes II. Comp. Blochem. Physiol., 78 A, 1984b: 799-807. POSPIŠIL, J. - KASE, F. - VAHALA, J. - MOUCHOVA, I.: Basic haematologica1 values in Antelopes III. Comp. Blochem. Physiol. 78 A, 1984c: 809-813.

POSPIŠIL, J. - KAŠE, F. - VAHALA, J. - MOUCHOVA, I.: Basic haematological values in Antelopes IV. Comp. Biochem. Physiol., 78 A, 1984d: 815-821.

POSPIŠIL, J. - KAŠ, F. - VAHALA, J.: Basic haematological values in the African Buffalo (Syncerus caffer caffer) and in the Red Buffalo (Syncerus caffer nanus). Comp. Biochem. Physio1., 82 A, 1985a: 495-498.

POSPIŠIL, J. - KOMAREK, J.: Peripheres Blutbild bel klinisch gesunden Hunden. Arch. exp. Vet. med., 17, 1963: 633-644.

POSPISIL, J. - VAHALA, J. - KAŠE, F. - FRAISOVA, L.: Haematological values in the Peripheral Blood of Zebras kept in the East Bohemian Zoological Garden at Dvůr Králové. Acta Vet. Brno, 54, 1985b: 129-140.

SCHALM, 0.W. - JAIN, N.C. - CARROL, E.J.: Veterinary Haematology, 3rd edition. Lea and Febiger, Philadelphia, 1975, 80 p.

SCHREIBER, V.: Stress, patofysiologie, endokrinologie, klinika. Avicenum, Praha $1985,383 \mathrm{p}$.

SOVA, Z.: Používání SI jednotek v zootechnice a veterinární medicině. Biologizace a chemizace živočišné výroby-veterinaria, 15(21), 1979: 295-301. 